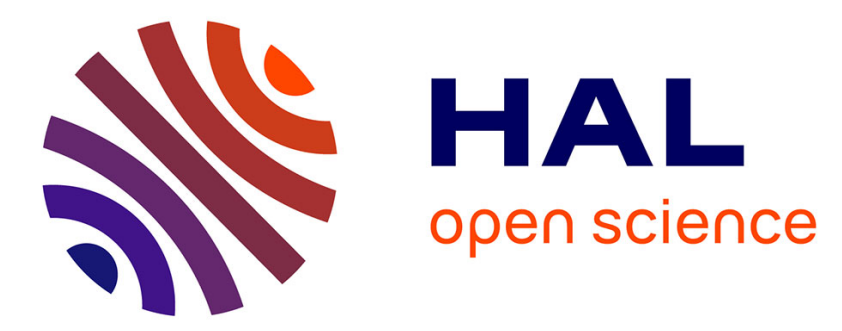

\title{
Microsatellite markers for the Baltic clam, Macoma balthica (Linné, 1758), a key species concerned by changing southern limit, in exploited littoral ecosystems.
}

\author{
Vanessa Becquet, L. Lanneluc, B. Simon-Bouhet, P. Garcia
}

\section{- To cite this version:}

Vanessa Becquet, L. Lanneluc, B. Simon-Bouhet, P. Garcia. Microsatellite markers for the Baltic clam, Macoma balthica (Linné, 1758), a key species concerned by changing southern limit, in exploited littoral ecosystems.. Conservation Genetics Resources, 2009, 1, pp.265-267. 10.1007/s12686-009-90650 . hal-00485678

\author{
HAL Id: hal-00485678 \\ https://hal.science/hal-00485678
}

Submitted on 21 May 2010

HAL is a multi-disciplinary open access archive for the deposit and dissemination of scientific research documents, whether they are published or not. The documents may come from teaching and research institutions in France or abroad, or from public or private research centers.
L'archive ouverte pluridisciplinaire HAL, est destinée au dépôt et à la diffusion de documents scientifiques de niveau recherche, publiés ou non, émanant des établissements d'enseignement et de recherche français ou étrangers, des laboratoires publics ou privés. 
Microsatellite markers for the Baltic clam, Macoma balthica (Linné, 1758), a key species concerned by changing southern limit, in exploited littoral ecosystems

V. Becquet, I. Lanneluc, B. Simon-Bouhet and P. Garcia

Littoral, Environnement et Sociétés (LIENSS) UMR 6250 CNRS-Université de La Rochelle, 2 Rue Olympe de Gouges, 17042 La Rochelle cedex, France

Keywords: range shift, global warning, Macoma balthica, microsatellite

Corresponding author :

Vanessa Becquet

Institut du Littoral et de l'Environnement, 2 rue Olympe de Gouges, 17000 La Rochelle, FRANCE

Fax : 0033546458264

vbecquet@univ-lr.fr 


\section{Abstract}

During the last 30 years, the southern European range limit of the Baltic clam Macoma balthica strongly shifted northward. To understand the consequences of such a retreat on populations located near the edge of its current geographic range, we developed nine microsatellite markers and tested their usefulness on 36 individuals from two populations. All loci were found to be polymorphic, with five to twenty-six alleles per locus. These results appear promising to study the fine scale genetic structure and dynamics of Macoma balthica populations near the range limit.

Parmesan \& Yohe (2003) recently showed that more than 1500 species had experienced switches in their biotic trends coherent with the twentieth century climate warming. In the northern hemisphere, a growing number of coastal marine mollusc species are concerned by northward shifts (Wethey \& Woodin 2008). However, consequences of such shifts on the function and structure of coastal ecosystems remain mostly unknown (Walther et al. 2002).

The Baltic clam Macoma balthica (Bivalvia: Tellinidae) is widely distributed in marine and estuarine soft-bottom habitats from temperate to arctic coastal waters in the North Atlantic and North Pacific oceans. Along the European coasts, its natural range is showing a strong shift toward the north-east and the species is rapidly vanishing from the Bay of Biscay (Jansen et al. 2007). As an important prey for migratory birds, macro-invertebrates and fish, M. balthica is one of the key-species along the European littoral (Philippart et al. 2003) and is thus of direct importance for fisheries and ecosystem conservation. Focusing on the current edge of its southern distribution, we aim to investigate the fine scale mechanisms of exchanges between unstable populations. Thus, we developed nine polymorphic 
microsatellite markers and tested their usefulness by analysing two populations respectively sampled near the range limit and in the core of the species distribution.

Genomic DNA from four individuals from the Waddensee (Dutch coast) was isolated from $<15 \mathrm{mg}$ of muscle using a Nucleospin tissue kit (Macherey Nagel). A genomic library enriched for CA repeated microsatellites was constructed following the protocol described by Billote et al. (1999). Briefly, total DNA was digested with RsaI (Promega). After purification on a Nucleospin Column (Macherey Nagel), $3 \mu \mathrm{g}$ of digested DNA was ligated to RsaI adapters (Rsa21F: 5'-CTCTTGCTTACGCGTGGACTA-3'and Rsa25R: 5'TAGTCCACGCGTAAGCAAGAGCACA-3'). For the enrichment procedure, hybridization of DNA fragments was carried out using biotinylated (AC) $)_{10}$ probes attached to streptavidincoated magnetic beads (Streptavidin Magnesphere ${ }^{\circledR}$ Paramagnetic Particles; Promega). The purified enriched fraction was ligated into pGEM®-T easy (Promega) and transformed into Escherichia coli DH5 $\alpha$ competent cells. Recombinants with appropriate insert sizes were determined by polymerase chain reaction ( 99 clones). From a total of 67 positive clones sequenced using a SequiTherm EXCEL ${ }^{\text {TM }}$ II DNA Sequencing Kit (Epicentre) on a Li-Cor NEN Global IR2 DNA sequencer, 37 primer pairs were designed using OLIGO $^{\circledR}$ v.6.0 (Rychlik \& Rychlik 2000). Forward primers were fluorescently-labelled with infra-red fluorescent dye IRD700 ${ }^{\mathrm{TM}}$ or IRD800 ${ }^{\mathrm{TM}}$ for screening. The genomic DNA for genotyping was obtained using Nucleospin tissue kit (Macherey Nagel). Amplification conditions were optimized for 9 loci (Table 1) for which preliminary tests showed unambiguous patterns. Each reaction was performed in $10 \mu \mathrm{l}$ and contained approximately $50 \mathrm{ng}$ of DNA, $0.25 \mu \mathrm{M}$ of fluorescently labelled forward primer, $0.25 \mu \mathrm{M}$ of unlabelled reverse primer, $1.5 \mathrm{mM}$ of $\mathrm{MgCl}_{2}, 0.2 \mathrm{mM}$ of each dNTP, 1X PCR buffer [75 mM Tris- $\mathrm{HCl}, \mathrm{pH} 8.8$ at $25^{\circ} \mathrm{C}, 20 \mathrm{mM}$ 
$\left(\mathrm{NH}_{4}\right)_{2} \mathrm{SO}_{4}$ and $0.01 \%$ Tween 20] and $0.5 \mathrm{U}$ of Thermoprime Plus DNA Polymerase (ABgene), using a MJ Research PTC-200 thermocycler (MJ research Inc.). Thermal cycling conditions followed a touch-down PCR procedure: 3 min of an initial denaturation step at $95^{\circ} \mathrm{C}$ followed by 10 cycles of denaturation at $95^{\circ} \mathrm{C}$ for $45 \mathrm{~s}$, annealing at temperature decreasing by $1{ }^{\circ} \mathrm{C}$ per cycle from Ti to Ta (Table 1) for $45 \mathrm{~s}$ and extension at $72^{\circ} \mathrm{C}$ for $45 \mathrm{~s}$, then followed by 30 cycles at $95^{\circ} \mathrm{C}$ for $45 \mathrm{~s}$, annealing at final $\mathrm{Ta}$ for $45 \mathrm{~s}$ and extension at $72^{\circ} \mathrm{C}$ for $45 \mathrm{~s}$. A final extension step was carried out for $7 \mathrm{~min}$ at $72^{\circ} \mathrm{C}$. PCR products were screened on a $6.5 \%$ polyacrylamide gel using a Li-Cor NEN Global IR2 DNA sequencer system. Allele sizes were determined using a known DNA sequence.

Polymorphism at the nine loci was tested in two populations of $M$. balthica [Fouras, $\mathrm{N}=15$ and Waddensee, $\mathrm{N}=21$ ]. No linkage disequilibria across loci were detected using GENEPOP version 4.0.7 (Raymond \& Rousset 1995). This software was also used to estimate the expected heterozygosities and adequacy of genotypic proportions to Hardy-Weinberg expectations (Table 1). Over the 36 individuals analysed, the number of alleles ranged from 5 to 26 and expected heterozygosis from 0.13 to 0.91 . At the population level, deviations from Hardy-Weinberg equilibrium were variable across loci and populations. The loci Mb-mac 10 showed a significant heterozygote deficiency for both populations, which might be due to null alleles. This hypothesis was tested using MICRO-CHECKER v.2.2.3 (Van Oosterhout 2004). It was confirmed for these loci that the heterozygote deficiency were not related to deviation from panmixia or genotyping errors but possibly to the presence of null alleles. Furthermore, all populations were found to be polymorphic [e.g. mean number of alleles: 8.00 and 7.22 in Fouras and Waddensee respectively]. 
Although care should be taken to accommodate null alleles, these microsatellites should prove useful for analyzing fine scale genetic structures, population dynamics, and relationships within and between local populations of Macoma balthica.

\section{References}

Billote N, Lagoda P, Risterucci AM, Baurens FC (1999) Microsatellite-enriched libraries: applied methodology for the tech development of SSR markers in tropical crops. Fruits, $\mathbf{5 4}$, $277-288$

Jansen JM, Pronker AE, Bonga SW, Hummel H (2007) Macoma balthica in Spain, a few decades back in climate history. Journal of Experimental Marine Biology and Ecology, 344, $161-169$

Parmesan C, Yohe G (2003) A globally coherent fingerprint of climate change impacts across natural systems. Nature, 421, 37-42.

Philippart CJM, Van Aken HM, Beukema JJ, Bos OG, Cadée GC, Dekker R (2003) Climaterelated changes in recruitment of the bivalve Macoma balthica. Limnology and Oceanography, 48, 2171-2185.

Raymond M, Rousset F (1995) GENEPOP (version1.2): a population genetics software for exact tests and ecumenicism. The Journal of Heredity, 86, 248-249.

Rychlik W, Rychlik P (2000) Oligo primer analysis software. Version 6.0.1. Cascade, Colorado. Molecular Biology Insights, Inc.

Van Oosterhout C, Hutchinson WF, Wills DPM, Shipley P (2004) MICRO-CHECKER: software for identifying and correcting genotyping errors in microsatellite data. Molecular Ecology Notes, 4, 535-538. 
Walther GR, Post E, Convey P, Menzel A, Parmesan C, Beebee TJC, Fromentin JM, HoeghGuldberg O, Bairlein F (2002) Ecological responses to recent climate change. Nature, 416, 389-395

Wethey DS, Woodin SA (2008) Ecological hindcasting of biogeographic responses to climate change in the European intertidal zone. Hydrobiologia, 606, 139-151.

\section{Acknowledgements}

We would like to thank Claire Daguin (Evolution et Génétique des Populations Marines, Roscoff) for improvement of the protocol. V. Becquet was supported by a grant from the Association Nationale de la Recherche Technique. 